University of Nebraska - Lincoln

DigitalCommons@University of Nebraska - Lincoln

\title{
Influence of fipronil compounds and rice-cultivation land-use intensity on macroinvertebrate communities in streams of southwestern Louisiana, USA
}

Scott V. Mize

U.S. Geological Survey, svmize@usgs.gov

Stephen D. Porter

U.S. Geological Survey

Dennis K. Demcheck

U.S. Geological Survey

Follow this and additional works at: https://digitalcommons.unl.edu/usgsstaffpub

Part of the Earth Sciences Commons

Mize, Scott V.; Porter, Stephen D.; and Demcheck, Dennis K., "Influence of fipronil compounds and ricecultivation land-use intensity on macroinvertebrate communities in streams of southwestern Louisiana, USA" (2008). USGS Staff -- Published Research. 435.

https://digitalcommons.unl.edu/usgsstaffpub/435

This Article is brought to you for free and open access by the US Geological Survey at DigitalCommons@University of Nebraska - Lincoln. It has been accepted for inclusion in USGS Staff -- Published Research by an authorized administrator of DigitalCommons@University of Nebraska - Lincoln. 


\title{
Influence of fipronil compounds and rice-cultivation land-use intensity on macroinvertebrate communities in streams of southwestern Louisiana, USA
}

\author{
Scott V. Mize ${ }^{a, *}$, Stephen D. Porter ${ }^{b}$, Dennis K. Demcheck ${ }^{a}$ \\ ${ }^{\text {a }}$ US Geological Survey, 3535 S. Sherwood Forest Blvd., Suite 120, Baton Rouge, LA 70816, USA \\ ${ }^{\mathrm{b}}$ US Geological Survey, Denver Federal Center, PO Box 25046, MS406, Lakewood, CO 80225, USA
}

Received 28 August 2006; received in revised form 13 March 2007; accepted 16 March 2007

Aquatic macroinvertebrate commmunities in southwestern Louisiana streams respond to a gradient of fipronil compounds in water.

\begin{abstract}
Laboratory tests of fipronil and its degradation products have revealed acute lethal toxicity at very low concentrations $\left(\mathrm{LC}_{50}\right)$ of $<0.5 \mu \mathrm{g} / \mathrm{L}$ to selected aquatic macroinvertebrates. In streams draining basins with intensive rice cultivation in southwestern Louisiana, USA, concentrations of fipronil compounds were an order of magnitude larger than the $\operatorname{LC}_{50}$. The abundance $(\rho=-0.64 ; p=0.015)$ and taxa richness $\left(r^{2}=0.515\right.$, $p<0.005)$ of macroinvertebrate communities declined significantly with increases in concentrations of fipronil compounds and rice-cultivation land-use intensity. Macroinvertebrate community tolerance scores increased linearly $\left(r^{2}=0.442, p<0.005\right)$ with increases in the percentage of rice cultivation in the basins, indicating increasingly degraded stream conditions. Similarly, macroinvertebrate community-tolerance scores increased rapidly as fipronil concentrations approached about $1 \mu \mathrm{g} / \mathrm{L}$. Pesticide toxicity index determinations indicated that aquatic macroinvertebrates respond to a gradient of fipronil compounds in water although stream size and habitat cannot be ruled out as contributing influences. Published by Elsevier Ltd.
\end{abstract}

Keywords: Fipronil; Macroinvertebrates; Pesticides; Louisiana; NAWQA

\section{Introduction}

Fipronil is a broad-spectrum insecticide that is in the phenylpyrazole class of pesticides. Since its introduction in 1996, fipronil has been used on rice, corn, and cotton (US Environmental Protection Agency, 1996); as well as in flea and tick sprays, household pest control products (e.g., roach and ant baits), and commercial turf care products (National Pesticide Telecommunications Network, 1997).

Fipronil is a unique compound with an average organic carbon partition coefficient $\left(K_{\text {oc }}\right)$ of 803 and a log octanol-water

\footnotetext{
* Corresponding author.

E-mail address: svmize@usgs.gov (S.V. Mize).
}

partition coefficient ( $\left.\log K_{\text {ow }}\right)$ of 4.01 (Connelly, 2001), and occurs in both dissolved and particulate phases. Fipronil has an affinity for natural organic matter present in soils or water. Water solubility of fipronil at $\mathrm{pH}$ of 5 is $0.0024 \mathrm{~g} / \mathrm{L}$ and at $\mathrm{pH} 9$ is $0.0022 \mathrm{~g} / \mathrm{L}$ (US Environmental Protection Agency, 1996). At typical environmental $\mathrm{pHs}$, fipronil in water is more susceptible to photodegradation (photolysis $T_{1 / 2}=4.1 \mathrm{~h}, \mathrm{pH} 5.5$ ) than hydrolysis (hydrolysis $T_{1 / 2}=1390$ days, $\mathrm{pH} 7.1$ at $22^{\circ} \mathrm{C}$ ) except under alkaline conditions (hydrolysis $T_{1 / 2}=32$ days at $\mathrm{pH} 9$ and 0.1 days, $\mathrm{pH} 12$ at $22{ }^{\circ} \mathrm{C}$ ). Fipronil on the soil surface is prone to photodegradation (photolysis $T_{1 / 2}=34$ days) and fipronil below the soil surface dissipates by soil binding (aerobic soil $T_{1 / 2}=630-693$ days; anaerobic soil $T_{1 / 2}=123$ days $)$ and gradual breakdown through microbial action (Connelly, 2001). 
Fipronil is toxic to many non-target organisms at environmentally relevant concentrations. Fipronil is highly toxic to fish, aquatic invertebrates, and upland game birds, but relatively less toxic to mammals, waterfowl, and other bird species (US Environmental Protection Agency, 1996). Ali et al. (1998) and Stevens et al. (1998) reported that chironomid midge larvae were susceptible to fipronil at very low lethal concentrations $\left(\mathrm{LC}_{50}=0.42 \mu \mathrm{g} / \mathrm{L}\right.$ and $0.43 \mu \mathrm{g} / \mathrm{L}$, respectively). Similarly, black fly larvae were determined to be even more susceptible to fipronil (Overmyer et al., 2005) at median concentrations ranging from $\mathrm{LC}_{50}=0.31-0.18 \mu \mathrm{g} / \mathrm{L}$ much lower than those reported for other macroinvertebrates. Fipronil is highly toxic to estuarine mysid shrimp $\left(\mathrm{LC}_{50}=0.14 \mu \mathrm{g} / \mathrm{L}\right)$, and can affect survival, reproduction, and growth at concentrations as low as $0.005 \mu \mathrm{g} / \mathrm{L}$ (US Environmental Protection Agency, 1996). Chandler et al. (2004) reported that fertility, reproduction, and development of an estuarine copepod were affected at fipronil concentrations of $0.22 \mu \mathrm{g} / \mathrm{L}$.

The degradation products of fipronil (fipronil sulfide, fipronil sulfone, and desulfinylfipronil) are more toxic to aquatic organisms than the parent compound. For example, desulfinylfipronil, a photodegradate of fipronil, is extremely stable and is more toxic than the parent compound (US Environmental Protection Agency, 1998). Fipronil sulfone and fipronil sulfide are 6.6 and 1.9 times, respectively, more toxic to freshwater invertebrates than fipronil (US Environmental Protection Agency, 1996).

Fipronil was used extensively throughout the Mermentau River Basin between 1999 and 2001 to help control the rice water weevil. Around that time, farmers with co-located rice and crawfish operations began reporting crawfish mortality in fields where fipronil-treated rice seed had been introduced (W.R. McClain, Advocate Newspaper, May 20, 2000; Mark Schleifstein, Times-Picayune newspaper, June 8, 1999). In October 1998, the US Geological Survey (USGS), as part of its National Water Quality Assessment (NAWQA) Program, began an assessment of the Acadian-Pontchartrain Drainages in southern Louisiana (Demcheck et al., 2004), which included a study of the occurrence and distribution of agricultural pesticides in the Mermentau River Basin (Demcheck and Skrobialowski, 2003; Skrobialowski et al., 2004). The USGS, concerned about the potential adverse effects of fipronil and its degradates on water quality and aquatic macroinvertebrate communities in the region, expanded the study and added fipronil compounds to the list of chemical analytes. Results from the investigation by Demcheck and Skrobialowski (2003) indicated that fipronil sulfone and sulfide accumulated in streambed sediments, with concentrations generally increasing from headwaters downstream to the Mermentau River. Skrobialowski et al. (2004) reported that fipronil was one of four significant $(p \leq 0.05)$ environmental factors related to the distribution of aquatic macroinvertebrate communities, and fipronil was related to decreases in relative abundance of many aquatic macroinvertebrate species. Skrobialowski et al. (2004) also reported that decreases in species abundance occurred at concentrations of fipronil degradation products (e.g., fipronil sulfone and sulfide) that were less than the fipronil parent compound concentrations.
In the current (2006) study, we investigated the distribution and influence of fipronil compounds and agricultural intensity (percentage of rice-cultivation land use) on macroinvertebrate communities at 19 stream locations in the Mermentau and Calcasieu River Basins in southwestern Louisiana, USA. The study was completed to further understand the relations of rice-cultivation pesticides, in particular fipronil compounds, in water and aquatic macroinvertebrate communities. This paper (1) describes the occurrence and distribution of fipronil compounds and other pesticides, using a pesticide toxicity index (PTI), and (2) assesses the influences of fipronil compounds and stream habitat conditions on aquatic macroinvertebrate communities. In this paper, we examine macroinvertebrate population and community responses to fipronil concentrations and compare tolerance responses to related physical and chemical factors associated with rice-cultivation intensity.

\section{Materials and methods}

\subsection{Study area}

The study area consisted of 19 streams locations in the Mermentau and Calcasieu River Basins in southwestern Louisiana (Fig. 1, Table 1). The basins are within the Western Gulf Coastal Plains ecoregion (Omernik, 1987). The Mermentau River Basin is located within wet prairie with clay and loamy soils that are used extensively for rice cultivation. Most of the land in the Mermentau River Basin has been altered as a result of agricultural land uses, mainly rice cultivation, but also includes soybean and sugarcane crops, pasture, and crawfish farming. The use of fipronil in the Mermentau and Calcasieu River Basins has been curtailed subsequent to reports of commercial crawfish kills in areas where fipronil-treated rice seed had been introduced (W.R. McClain, Advocate Newspaper, May 20, 2000; Mark Schleifstein, Times-Picayune Newspaper, June 8, 1999), and fipronil was voluntarily deregistered for rice in 2005. The Calcasieu River Basin primarily is forested, and is located within rolling pine hills with sandy soils.

\subsection{Study design}

Sites were selected to represent water-quality conditions influenced by agricultural intensity as indicated by the percentage of the basins used for rice cultivation. Sites in the study with at least $45 \%$ of the drainage area used for rice cultivation were considered high-intensity; otherwise, sites were considered low-intensity (Table 1). Sites with drainage areas greater than or equal to $70 \mathrm{mi}^{2}$ were considered large basins, and those smaller than $70 \mathrm{mi}^{2}$ were considered small basins (Table 1).

Three depth and width-integrated water samples were collected at all sites except one in which two samples were collected between March and May 2001 for determination of pesticides. Procedures used to collect and process water samples followed standard USGS guidelines described by the US Geological Survey (2001), Shelton (1994), Gilliom et al. (1995), and Mueller et al. (1997). Water samples were analyzed at the USGS National Water Quality Laboratory (NWQL) in Denver, CO, USA, using methods described by Fishman and Friedman (1989), Sandstrom et al. (1992), Sandstrom (1995), Zaugg et al. (1995), and Madsen et al. (2003). The analyses included fipronil and three fipronil degradation products and 15 other pesticides.

Aquatic macroinvertebrate samples and stream habitat measurements were collected once during the spring (March-April 2001). Macroinvertebrate samples were collected from submerged woody debris (snags) in richest-targeted habitat as described by Moulton et al. (2002). Organisms were removed within a specific area, preserved in a $10 \%$ formalin solution, and shipped to the USGS NWQL. At the laboratory, macroinvertebrate samples were subsampled, sorted, and identified to the lowest practical taxonomic level, using procedures outlined in Moulton et al. (2000). 


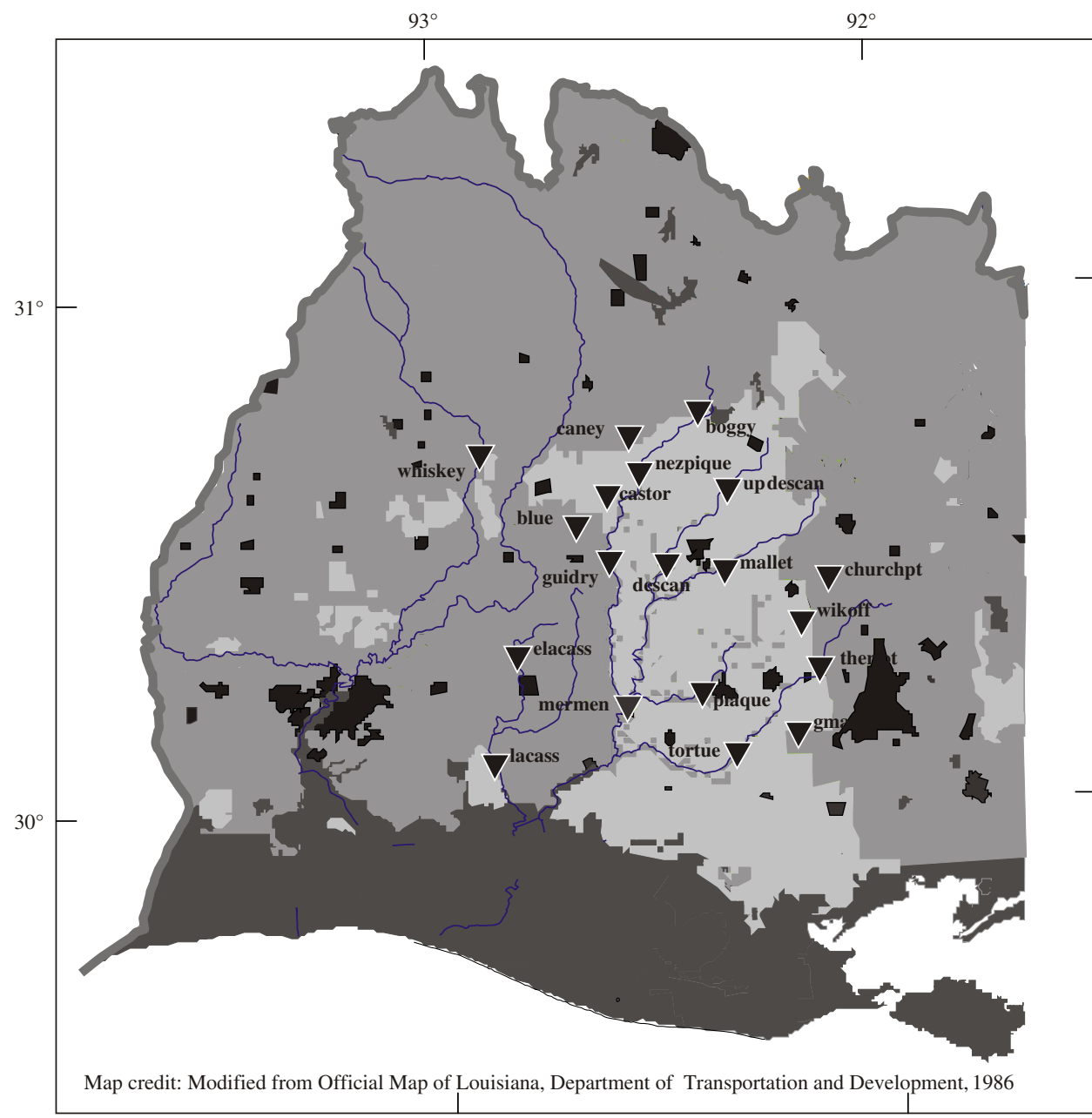

\section{EXPLANATION}

Land-use data

(source: Joseph Hol mes, Lou isiana

Department of Environmental Quality, written commun., 2001)
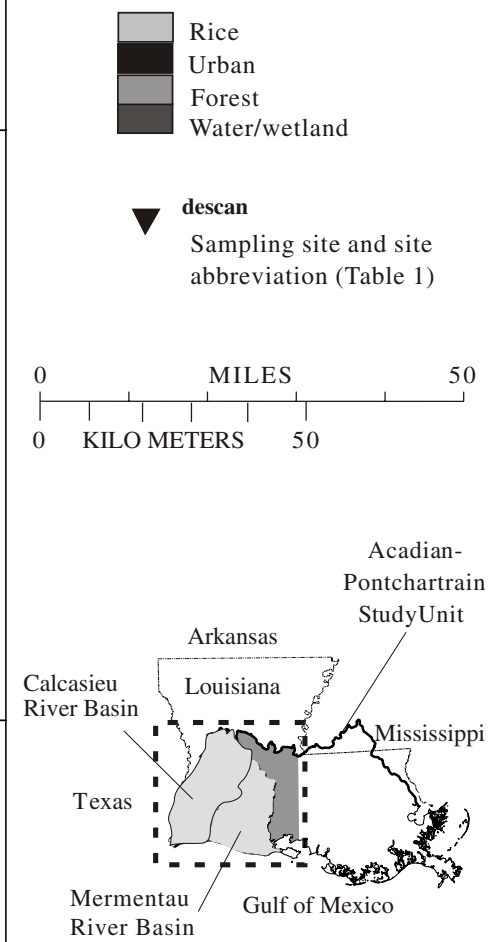

Index Map

Fig. 1. Land use and sampling sites in southwestern Louisiana, 2001.

Stream habitat measurements were made at or near the time of macroinvertebrate sample collection. A quantitative assessment of physical habitat conditions included instream characteristics (such as stream width, stream depth, velocity, Secchi depth, and bed-material size distribution) and riparian characteristics (such as bank structure, riparian vegetation, and canopy cover) at 11 equally spaced transects in a stream reach. Stream habitat data were collected following procedures in Fitzpatrick et al. (1998)

\subsection{Pesticide toxicity index (PTI) determination}

The PTI was calculated by summing, for all pesticides analyzed in a water sample, the individual pesticide concentration divided by its laboratory-based toxicity concentration or $\mathrm{LC}_{50}$, to obtain an index of potential toxicity to aquatic organisms (Munn and Gilliom, 2001). The PTI was calculated only for aquatic macroinvertebrates. Evaluation of the actual duration and exposure of aquatic macroinvertebrates to pesticide concentrations was not possible in this study. Instead, maximum concentrations of pesticides detected were used in all PTI calculations under the assumption that (1) the acute risk or short-term exposure of aquatic macroinvertebrates was expected to respond to the maximum insecticide concentration rather than a mean or median concentration, and (2) potential acute toxicity likely was underestimated because of relatively infrequent water-quality sampling (monthly) during the synoptic study. The probability of sampling peak concentrations may be low in waterquality monitoring surveys (Munn and Gilliom, 2001).

Toxicity data for fipronil (Table 2) were obtained from recent toxicity literature for macroinvertebrate species commonly sampled in southern Louisiana. $\mathrm{LC}_{50}$ values were complied for fipronil from toxicity tests for chironomid, mosquito, and black fly larvae as described by Ali et al. (1998),
Stevens et al. (1998), and Overmyer et al. (2005), and a median LC $_{50}$ of $0.42 \mu \mathrm{g} / \mathrm{L}$ for fipronil was used to calculate the PTI for aquatic macroinvertebrates. Because $\mathrm{LC}_{50}$ data are currently (2006) limited for fipronil degradation products, an estimate of the relative potential toxicity for fipronil sulfide and fipronil sulfone to aquatic macroinvertebrates was based on the USEPA conclusion that fipronil sulfide is 1.9 times more toxic, and fipronil sulfone is 6.6 times more toxic, to freshwater macroinvertebrates than the parent compound (US Environmental Protection Agency, 1996). The $\mathrm{LC}_{50}$ values for fipronil sulfide $(0.22 \mu \mathrm{g} / \mathrm{L})$ and fipronil sulfone $(0.06 \mu \mathrm{g} / \mathrm{L})$ were estimated by dividing the median $\mathrm{LC}_{50}$ for the fipronil parent compound $(0.42 \mu \mathrm{g} / \mathrm{L})$ by 1.9 and 6.6, respectively. The relative potential toxicity of fipronil compounds to aquatic macroinvertebrates was compared with 15 other pesticides for which toxicity information was available.

The PTI was calculated using two methods to illustrate the relative toxicity of fipronil degradation products and their contribution to the PTI. First, the PTI $_{\text {parent }}$ and the percent contribution of fipronil to the PTI $\mathrm{Parent}_{\text {were calcu- }}$ lated using concentrations of 16 detected parent pesticides. Second, the PTI ${ }_{\text {total }}$ was calculated for the same 16 parent pesticides plus three fipronil degradation products, and the percentage contribution of total fipronil (defined as the sum of the concentrations of fipronil, fipronil sulfide, fipronil sulfone, and desulfinylfipronil) to the $\mathrm{PTI}_{\text {total }}$ was calculated. Because $\mathrm{LC}_{50}$ data are currently (2006) limited for desulfinylfipronil, this photodegradation compound was assumed to be equally toxic as fipronil (Hainzl and Casida, 1996).

\subsection{Statistical analysis}

Aquatic macroinvertebrate and stream habitat measurement data were summarized and compared to the PTI and concentrations of fipronil and 
Table 1

Description of sampling sites in southwestern Louisiana, March-May 2001

\begin{tabular}{|c|c|c|c|}
\hline Site name & $\begin{array}{l}\text { Abbreviated } \\
\text { site name }\end{array}$ & $\begin{array}{l}\text { Drainage area } \\
\text { (square miles) }\end{array}$ & $\begin{array}{l}\text { Percentage } \\
\text { of basin } \\
\text { used for rice } \\
\text { cultivation }\end{array}$ \\
\hline $\begin{array}{l}\text { Boggy Bayou } \\
\text { at LA-Hwy. } \\
106 \text { near } \\
\text { Pine Prairie }\end{array}$ & Boggy & 65 & 0.0 \\
\hline $\begin{array}{l}\text { Caney Creek } \\
\text { at Bond Road } \\
\text { near Oakdale }\end{array}$ & Caney & 18 & 0.0 \\
\hline $\begin{array}{l}\text { Whiskey Chitto } \\
\text { Creek near Oberlin } \\
\text { at LA-Hwy. } 26\end{array}$ & Whiskey & 504 & 8.0 \\
\hline $\begin{array}{l}\text { Bayou Nezpique } \\
\text { at LA-Hwy. } 376, \\
12.5 \text { mi north } \\
\text { of Basile }\end{array}$ & Nezpique & 166 & 21.7 \\
\hline $\begin{array}{l}\text { Bayou Plaquemine } \\
\text { Brule at LA-Hwy. } \\
370 \text { near Church Point }\end{array}$ & Churchpt & 74 & 25.7 \\
\hline $\begin{array}{l}\text { Bayou Nezpique } \\
\text { at Guidry Road } \\
\text { north of Basile }\end{array}$ & Guidry & 381 & 36.6 \\
\hline $\begin{array}{l}\text { Bayou Grand Marais } \\
\text { at LA-Hwy. } \\
699 \text { near Kaplan }\end{array}$ & Gmarais & 26 & 38.5 \\
\hline $\begin{array}{l}\text { Castor Creek } \\
\text { at Cottongin Castor } \\
\text { Road near Oberlin }\end{array}$ & Castor & 33 & 42.4 \\
\hline $\begin{array}{l}\text { Bayou Blue at LA-Hwy. } \\
26 \text { near Elton }\end{array}$ & Blue & 80 & 53.8 \\
\hline $\begin{array}{l}\text { Bayou Wikoff near } \\
\text { Rayne }\end{array}$ & Wikoff & 63 & 54.0 \\
\hline $\begin{array}{l}\text { Bayou Queue } \\
\text { de Tortue at Theriot } \\
\text { Road near Rayne }\end{array}$ & Theriot & 37 & 62.2 \\
\hline $\begin{array}{l}\text { Bayou Plaquemine } \\
\text { Brule at Estherwood }\end{array}$ & Plaque & 320 & 64.7 \\
\hline $\begin{array}{l}\text { Mermentau River } \\
\text { at Mermentau }\end{array}$ & Mermen & 1381 & 66.5 \\
\hline $\begin{array}{l}\text { Bayou Queue } \\
\text { de Tortue at LA-Hwy. } \\
13 \text { near Lelieux }\end{array}$ & Tortue & 97 & 74.2 \\
\hline $\begin{array}{l}\text { Bayou Mallet at LA-Hwy. } \\
367 \text { near Eunice }\end{array}$ & Mallet & 91 & 86.8 \\
\hline $\begin{array}{l}\text { Bayou Lacassine } \\
\text { near Lake Arthur }\end{array}$ & Lacass & 296 & 89.5 \\
\hline $\begin{array}{l}\text { Bayou des Cannes } \\
\text { at LA-Hwy. } 104 \text { near } \\
\text { Ville Platte }\end{array}$ & Updescan & 46 & 91.3 \\
\hline $\begin{array}{l}\text { Bayou des Cannes } \\
\text { near Eunice }\end{array}$ & Descan & 142 & 95.0 \\
\hline $\begin{array}{l}\text { East Bayou } \\
\text { Lacassine at LA-Hwy. } \\
99 \text { north of Welsh }\end{array}$ & Elacass & 15 & 100 \\
\hline
\end{tabular}

fipronil degradation products in water. When appropriate, log transformations of pesticide and stream habitat measurement data and natural log or squareroot transformations of aquatic macroinvertebrate community data were performed to meet normality assumptions of certain statistical tests. The mean values of quantitative habitat measurements for each site reach were used for analysis of habitat data.

Aquatic macroinvertebrate community data were processed using the Invertebrate Data Analysis System (IDAS, version 2.0.6; Cuffney, 2003).
Table 2

Acute toxicity (median lethal concentration $\left(\mathrm{LC}_{50}\right)$ ) of fipronil to aquatic macroinvertebrates.

\begin{tabular}{lll}
\hline $\begin{array}{l}\text { Aquatic macroinvertebrate } \\
\text { species }\end{array}$ & $\begin{array}{l}\text { Median } \mathrm{LC}_{50} \text { value } \\
(\mu \mathrm{g} / \mathrm{L})\end{array}$ & Source \\
\hline $\begin{array}{l}\text { Chironomus crassicaudatus } \\
\text { (midge larvae) }\end{array}$ & 0.42 & Ali et al. (1998) \\
$\begin{array}{c}\text { Glyptotendipes paripes } \\
\text { (midge larvae) }\end{array}$ & 0.42 & Ali et al. (1998) \\
$\begin{array}{c}\text { Chironomus tepperi } \\
\text { (midge larvae) }\end{array}$ & 0.43 & Stevens et al. (1998) \\
$\begin{array}{c}\text { Aedes taeniorhynchus } \\
\text { (mosquito larvae) }\end{array}$ & 0.43 & Ali et al. (1998) \\
$\begin{array}{c}\text { Simulium vittatum } \\
\text { (black fly larvae) }\end{array}$ & 0.24 & Overmyer et al. (2005) \\
\hline
\end{tabular}

Ambiguous taxa (e.g., the occurrence of family and generic level taxa in the same sample: Chironomidae vs Chironomus) were resolved in all samples by distributing the abundance of lower-level taxa (e.g., genera) among higher-level taxa (e.g., family or order). Organisms that were difficult or impossible to identify in samples (e.g., damaged specimens or early life stages), terrestrial adults, and rare taxa (occurring at only one site) were eliminated from the final analysis. Aquatic macroinvertebrate community metrics were calculated in IDAS and analyzed statistically from this processed data.

Exploratory analysis of environmental variables (e.g., concentrations of fipronil compounds and stream habitat variables) was performed using principal components analysis (CANOCO version 4; ter Braak and Smilauer, 1998) to reduce the number of environmental variables. A surrogate variable was selected from groups of correlated variables.

Macroinvertebrate community metrics and the relative abundance of common macroinvertebrate taxa were examined in relation to environmental variables using Spearman rank correlation test (SYSTAT version 8; Wilkinson et al., 1998) and linear regression (SYSTAT version 8; Wilkinson and Coward, 1998). Macroinvertebrate abundance-weighted tolerance values were calculated by weighting the tolerance value (Barbour et al., 1999) by the abundance of the organism in the sample. Tolerance values were based on a scale from 0 to 10, where 0 represented the tolerance value of an extremely sensitive organism, and 10 represented the value for a tolerant organism. Thus, a higher abundance-weighted tolerance value indicated that the communities at these sites consisted of more organisms considered tolerant to organic enrichment.

The distribution of aquatic macroinvertebrate communities (38 taxa) among sampling sites was evaluated using non-metric multidimensional scaling (NMDS) (Kruskal, 1964; Clarke, 1993; Clarke and Warwick, 2001). The NMDS is an iterative, non-parametric ordination procedure that makes relatively few assumptions about the structure or inter-relation of species or sites, and constructs a configuration plot of sites that attempts to satisfy conditions given by a distance or similarity matrix based on species and site ranks. Distortion between similarity rankings and corresponding distance rankings in a two-dimensional ordination plot is indicated by a stress value that measures "goodness-of-fit" of the ordination relation. PRIMER version 6 beta (Clarke and Warwick, 2001) was used to generate a Bray-Curtis similarity matrix based on square-root transformed relative-abundance data that were used for the NMDS ordination. Relations of environmental variables (e.g., pesticide concentrations, land-use intensity, habitat conditions), with NMDS site configurations based on macroinvertebrate community structure, were examined using the bubble plot function of PRIMER to identify important factors that may have influenced the structure of aquatic macroinvertebrate communities.

\section{Results}

\subsection{Occurrence and distribution of fipronil compounds}

Fipronil compounds (fipronil, fipronil sulfide, fipronil sulfone, and desulfinylfipronil) were detected in more than $78 \%$ of water samples from the study area. Fipronil degradation 
products were detected with greater frequency than fipronil (the parent compound) in water samples. Fipronil sulfide accounted for the greatest frequency of detection (90\%) followed by desulfinylfipronil $(88.3 \%)$, fipronil sulfone $(81.7 \%)$, and fipronil (78.3\%) (Table 3). Fipronil, fipronil sulfide, and desulfinylfipronil were detected at all sites except one, whereas fipronil sulfone was detected at 16 of the 19 sites.

Concentrations of fipronil compounds varied in streams draining high-intensity agricultural areas. Concentrations of fipronil ranged from less than 0.004 to $6.41 \mu \mathrm{g} / \mathrm{L}$. Concentrations of fipronil in water were highest during April and May following the release of rice-field tail waters, rather than being associated with seasonal differences in climate or streamflow. Maximum concentrations of fipronil occurred concurrently with concentrations of molinate, a herbicide commonly applied to rice fields. By contrast, maximum concentrations of atrazine, a broad-spectrum herbicide, occurred about a month earlier than maxima for fipronil and molinate. Although atrazine is not used as a herbicide for rice cultivation, it is used extensively on other crops in the study area.

Typically, concentrations of fipronil degradation products were detected at lower concentrations in the spring than early summer. Concentrations of desulfinylfipronil and sulfone were associated with concentrations of fipronil in water. Generally, as concentrations of fipronil increased, concentrations of desulfinylfipronil and sulfone increased. Maximum concentrations of desulfinylfipronil occurred concurrently with maximum concentrations of fipronil at 16 of 18 sites $(88.8 \%)$, most likely indicating that photodegradation of fipronil to desulfinylfipronil occurs rapidly while relatively large amounts of the parent compound are present in water. Maximum concentrations of the oxidation product, sulfone, occurred concurrently with maximum concentrations of fipronil at 13 of 16 sites $(81.2 \%)$ where sulfone was detected. Concentrations of sulfide steadily increased over the sample period indicating the reduction of fipronil to sulfone occurs at a relatively consistent rate.

\subsection{Contributions of fipronil to the PTI}

Fipronil compounds were the insecticide constituents detected most frequently in more than $78 \%$ of water samples analyzed during the study; however, the insecticides diazinon, malathion, carbaryl, and carbofuran were detected in $45.9 \%$, $26.2 \%, 16.7 \%$, and $9.8 \%$ of the samples, respectively (Table 3). Maximum concentrations of fipronil sulfone, fipronil sulfide, and fipronil were more than twice the median $\mathrm{LC}_{50}$ for those compounds. Atrazine was the most frequently detected herbicide in more than $96 \%$ of the samples. Concentrations of the herbicides molinate, tebuthiuron, metolachlor, and simazine were detected in $88.5 \%, 82.0 \%, 78.7 \%$, and $24.6 \%$ of the samples, respectively (Table 3). However, concentrations of six other common herbicides (Table 3) generally were detected in less than $20 \%$ of the samples.

The relative potential toxicity of fipronil compounds is substantially higher than 15 other detected pesticides for which toxicity information was available. Other pesticides were less than $4 \%$ as toxic as fipronil (Table 3). Malathion was the second most toxic parent pesticide detected in the study (3.5\% as toxic as fipronil), whereas carbaryl and carbofuran were the next most toxic pesticides (about $2.5 \%$ of relative fipronil toxicity). Using estimates for fipronil sulfide and fipronil sulfone (Table 3), fipronil was $14 \%$ as toxic as fipronil sulfone and $52 \%$ as toxic as fipronil sulfide.

The combination of relatively large total fipronil concentrations and a large percentage contribution of total fipronil compounds at those sites resulted in the $\mathrm{PTI}_{\text {total }}$ to be larger than the

Table 3

Occurrence, concentration, and relative toxicity of pesticides and degradation products at sampling sites in southwestern Louisiana, March-May 2001

\begin{tabular}{|c|c|c|c|c|c|c|c|c|}
\hline Pesticide name & $\begin{array}{l}\text { Pesticide } \\
\text { type }\end{array}$ & $\begin{array}{l}\text { Minimum reporting } \\
\text { level }(\mu \mathrm{g} / \mathrm{L})\end{array}$ & $\begin{array}{l}\text { Samples with } \\
\text { detected } \\
\text { concentrations } \\
\text { (percent) }\end{array}$ & $\begin{array}{l}\text { Median } \\
\text { concentration } \\
(\mu \mathrm{g} / \mathrm{L})\end{array}$ & $\begin{array}{l}\text { Maximum } \\
\text { concentration } \\
(\mu \mathrm{g} / \mathrm{L})\end{array}$ & $\begin{array}{l}\text { Median } \mathrm{LC}_{50} \\
(\mu \mathrm{g} / \mathrm{L})\end{array}$ & $\begin{array}{l}\text { Toxicity, } \\
\text { relative } \\
\text { to fipronil }\end{array}$ & Median LC $_{50}$ Source \\
\hline Fipronil sulfone & Insecticide & 0.001 & 81.7 & 0.0235 & 0.282 & 0.06 & 7.000000 & USEPA (1996) \\
\hline Fipronil sulfide & Insecticide & 0.01 & 90.0 & 0.0225 & 0.507 & 0.22 & 1.900000 & USEPA (1996) \\
\hline Fipronil & Insecticide & 0.004 & 78.3 & 0.2305 & 6.41 & 0.42 & 1.000000 & Current study \\
\hline Desulfinylfipronil & Insecticide & 0.01 & 88.3 & 0.071 & 1.54 & NA & NA & NA \\
\hline Malathion & Insecticide & 0.027 & 26.2 & 0.027 & 0.113 & 12 & 0.035000 & Munn and Gilliom (2001) \\
\hline Carbaryl & Insecticide & 0.041 & 16.7 & 0.041 & 0.041 & 16 & 0.026250 & Munn and Gilliom (2001) \\
\hline Carbofuran & Insecticide & 0.02 & 9.8 & 0.02 & 0.08 & 16.5 & 0.025455 & Munn and Gilliom (2001) \\
\hline Diazinon & Insecticide & 0.005 & 45.9 & 0.005 & 0.161 & 25 & 0.016800 & Munn and Gilliom (2001) \\
\hline Pendimethalin & Herbicide & 0.01 & 11.5 & 0.01 & 0.125 & 280 & 0.001500 & WSSA (1994) \\
\hline Thiobencarb & Herbicide & 0.005 & 8.2 & 0.005 & 0.799 & 1000 & 0.000420 & Munn and Gilliom (2001) \\
\hline Molinate & Herbicide & 0.002 & 88.5 & 0.469 & 89.6 & 4500 & 0.000093 & Munn and Gilliom (2001) \\
\hline Atrazine & Herbicide & 0.007 & 96.7 & 0.098 & 5.83 & 9000 & 0.000047 & Munn and Gilliom (2001) \\
\hline Simazine & Herbicide & 0.011 & 24.6 & 0.011 & 0.099 & 13000 & 0.000032 & Munn and Gilliom (2001) \\
\hline Propanil & Herbicide & 0.011 & 19.7 & 0.011 & 0.282 & 16000 & 0.000026 & Munn and Gilliom (2001) \\
\hline Alachlor & Herbicide & 0.002 & 3.3 & 0.002 & 0.009 & 19600 & 0.000021 & Munn and Gilliom (2001) \\
\hline EPTC & Herbicide & 0.002 & 6.6 & 0.002 & 0.012 & 23000 & 0.000018 & Munn and Gilliom (2001) \\
\hline Metolachlor & Herbicide & 0.013 & 78.7 & 0.013 & 0.684 & 25000 & 0.000017 & WSSA (1994) \\
\hline Prometon & Herbicide & 0.015 & 18.0 & 0.015 & 0.27 & 35000 & 0.000012 & WSSA (1989) \\
\hline Tebuthiuron & Herbicide & 0.016 & 82.0 & 0.03 & 0.21 & 225000 & 0.000001 & Frear and Boyd (1967) \\
\hline
\end{tabular}

USEPA, US Environmental Protection Agency. NA, data not available. WSSA, Weed Science Society of America. 
PTI $_{\text {parent }}$ for all sites where fipronil compounds were detected

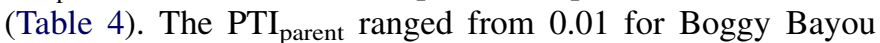
(Fig. 1; boggy) to 15.26 for Bayou Blue (blue). The percentage contribution of fipronil to the $\mathrm{PTI}_{\text {parent }}$ ranged from 92 to $100 \%$ at all sites where fipronil compounds were detected, except Bayou Plaquemine Brule near Church Point (churchpt) where the contribution was $79 \%$ (Table 4). The $\mathrm{PTI}_{\text {total }}$ was at least $50 \%$ larger than the $\mathrm{PTI}_{\text {parent }}$ at all sites where fipronil compounds were detected, and ranged from 0.02 for Boggy Bayou (boggy) to 23.40 for Bayou Blue (blue). The percent contribution of total fipronil to the $\mathrm{PTI}_{\text {total }}$ increased at all sites where fipronil compounds were detected and ranged from 97 to $100 \%$ except for Bayou Plaquemine Brule near Church Point (churchpt) (88\%). Fipronil when present dominates potential toxicity at these sites. The PTIs increased as concentrations of fipronil compounds increased, especially when other pesticides were insignificant; PTI was a function of fipronil concentration. Fipronil degradation products substantially increased potential toxicity at these sites.

\subsection{Aquatic macroinvertebrate communities as water- quality indicators}

Aquatic macroinvertebrate communities of streams in the study area were dominated primarily by true flies (Diptera) and non-insects, particularly scuds (Amphipoda), snails (Gastropoda), and aquatic worms (Oligochaeta). True flies were the most diverse taxa, followed by beetles (Coleoptera), caddisflies (Trichoptera), mayflies (Ephemeroptera), and snails. About 23,000 organisms were collected during the study.
The total abundance (organisms per square meter) of macroinvertebrates was smallest at sites with high maximum fipronil concentrations $(\rho=-0.64 ; p=0.015)$, particularly those exceeding the median $\mathrm{LC}_{50}(0.42 \mu \mathrm{g} / \mathrm{L} ; \mathrm{Fig} .2 \mathrm{~A})$. Total abundance increased slightly at several sites where maximum concentrations of fipronil varied from about 0.5 to $3.0 \mu \mathrm{g} / \mathrm{L}$; however, the presence of considerable aquatic vegetation and a corresponding increase in the abundance of non-insects at these sites most likely accounts for increases in total abundance. The abundance of certain midge taxa (Orthocladiinae and Tanytarsini) was smallest at sites with high maximum concentrations of fipronil, and the abundance of these taxa declined rapidly with small increases in fipronil concentrations (Fig. 2B). Taxa richness, the total number of taxa identified in macroinvertebrate samples, also declined linearly with increases in fipronil concentrations $\left(r^{2}=0.515, p<0.005\right.$; Fig. 3A). In particular, the number of Chironominae and Orthocladinae taxa (Fig. 3B) was smaller at sites with maximum fipronil concentrations exceeding the estimated $\mathrm{LC}_{50}$ for fipronil.

Macroinvertebrate community tolerance scores (Barbour et al., 1999) increased linearly $\left(r^{2}=0.442, p<0.005\right)$ with increases in the percentage of rice cultivation in stream basins (Fig. 4A), indicating increasingly degraded stream conditions. With respect to maximum fipronil concentrations, communitytolerance scores exhibited a threshold response at about $1 \mu \mathrm{g} / \mathrm{L}$ (Fig. 4B) with relatively little change in inferred stream condition (scores larger than 7) where fipronil concentrations exceeded this level.

Results of NMDS (Clarke and Warwick, 2001) based on the relative abundance of 38 common macroinvertebrate taxa

Table 4

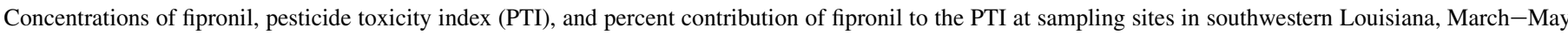
2001

\begin{tabular}{|c|c|c|c|c|c|c|}
\hline $\begin{array}{l}\text { Site } \\
\text { abbreviation }\end{array}$ & $\begin{array}{l}\text { Maximum }^{\mathrm{a}} \\
\text { concentration } \\
\text { of fipronil } \\
(\mu \mathrm{g} / \mathrm{L})\end{array}$ & $\begin{array}{l}\text { Total fipronil } \\
\text { concentration } \\
(\mu \mathrm{g} / \mathrm{L})\end{array}$ & $\begin{array}{l}\mathrm{PTI}_{\text {parent }}{ }^{\mathrm{c}} \text { for } \\
\text { macroinverte- } \\
\text { brates }\end{array}$ & $\begin{array}{l}\text { Percent } \\
\text { contribution } \\
\text { of fipronil to } \\
\text { the } \text { PTI }_{\text {parent }}\end{array}$ & $\begin{array}{l}\mathrm{PTI}_{\text {total }}^{\mathrm{d}} \text { for } \\
\text { macroinverte- } \\
\text { brates }\end{array}$ & $\begin{array}{l}\text { Percent contribution } \\
\text { of total fipronil } \\
\text { to the total } \mathrm{PTI}_{\text {total }} \mathrm{d}\end{array}$ \\
\hline Descan & 3.96 & 4.96 & 9.44 & 100 & 15.37 & 100 \\
\hline Wikoff & 0.03 & 0.11 & 0.08 & 94 & 0.55 & 99 \\
\hline Plaque & 1.89 & 2.46 & 4.51 & 100 & 7.62 & 100 \\
\hline Boggy & 0.00 & 0.01 & 0.01 & 92 & 0.02 & 97 \\
\hline Castor & 2.76 & 3.64 & 6.57 & 100 & 11.76 & 100 \\
\hline Nezpique & 1.48 & 1.80 & 3.53 & 100 & 5.25 & 100 \\
\hline Mermen & 1.37 & 1.98 & 3.27 & 100 & 6.90 & 100 \\
\hline Lacass & 0.90 & 1.10 & 2.15 & 99 & 3.31 & 100 \\
\hline Whiskey & 0.00 & 0.00 & 0.00 & 0 & 0.00 & 0 \\
\hline Tortue & 1.86 & 2.42 & 4.43 & 100 & 7.74 & 100 \\
\hline Gmarais & 0.32 & 0.44 & 0.77 & 100 & 1.35 & 100 \\
\hline Theriot & 0.29 & 0.57 & 0.70 & 98 & 2.31 & 99 \\
\hline Elacass & 0.18 & 0.56 & 0.43 & 98 & 3.27 & 100 \\
\hline Churchpt & 0.04 & 0.06 & 0.13 & 79 & 0.23 & 88 \\
\hline Mallet & 0.44 & 0.69 & 1.05 & 100 & 2.42 & 100 \\
\hline Guidry & 2.15 & 2.65 & 5.12 & 100 & 8.44 & 100 \\
\hline Blue & 6.41 & 7.67 & 15.26 & 100 & 23.40 & 100 \\
\hline Updescan & 3.85 & 5.77 & 9.17 & 100 & 16.96 & 100 \\
\hline Caney & 0.01 & 0.01 & 0.01 & 97 & 0.02 & 98 \\
\hline
\end{tabular}

\footnotetext{
a Maximum concentration during the sampling period.

b Total fipronil is the sum of the maximum concentrations of fipronil, fipronil sulfide, fipronil sulfone, and desulfinylfipronil.

c Pesticide toxicity index (PTI) calculated for 16 parent pesticides.

d Total pesticide toxicity index calculated for 16 parent pesticides and three fipronil degradates.
} 

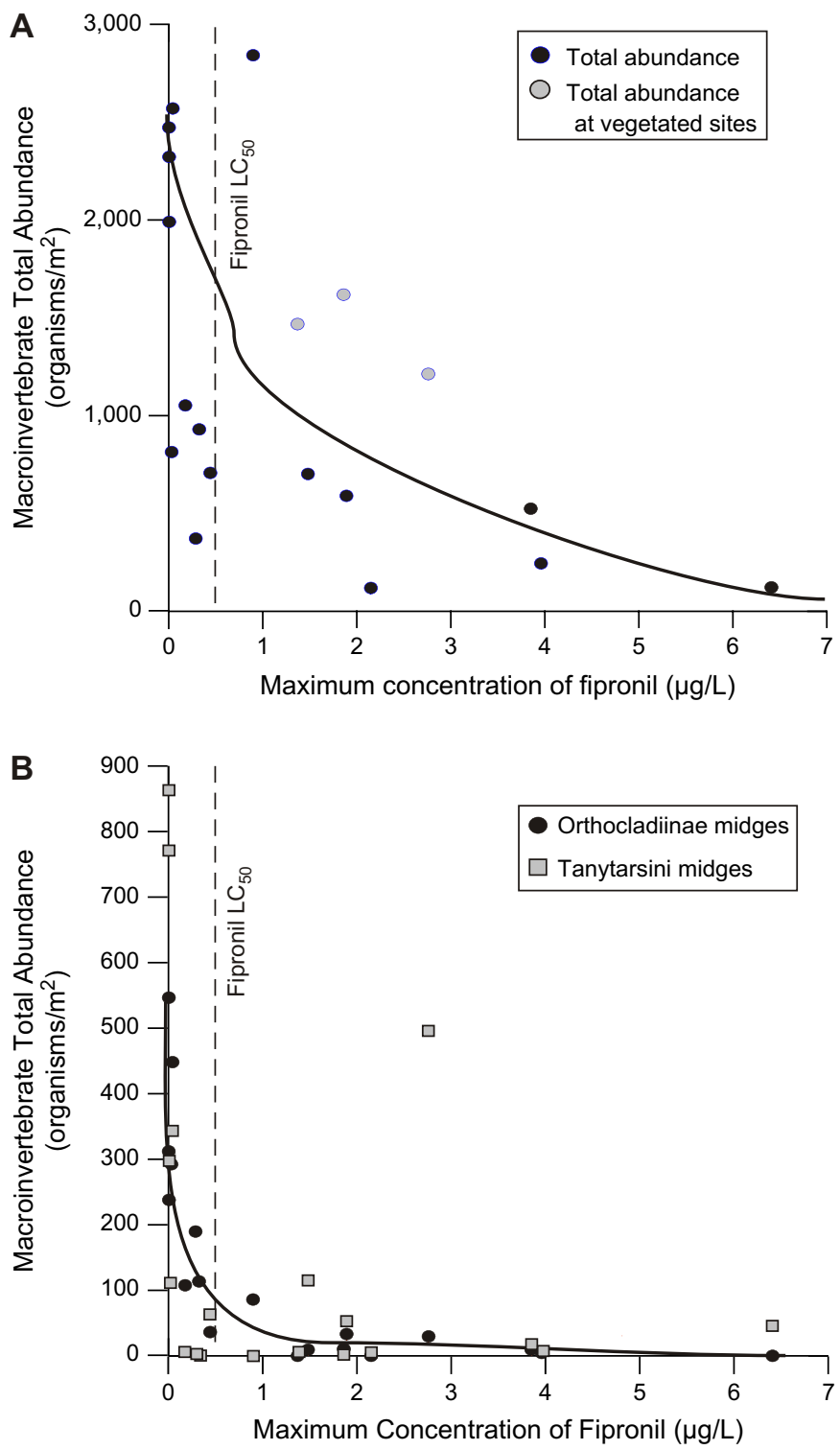

Fig. 2. Relations among total abundance of macroinvertebrates and abundance of Orthocladiinae and Tanytarsini midges and maximum concentrations of fipronil at sampling sites in southwestern Louisiana, March-May 2001.

revealed a spatial distribution of sites associated with differences in percentage of rice cultivation, PTI scores, maximum fipronil concentrations, Secchi disk depth, stream wetted channel width, and percentage open canopy. For example, headwater streams in the northern part of the study area (Fig. 5, Group A) were characterized by low agricultural intensity (percentage rice cultivation), low PTI scores and fipronil concentrations, and high water clarity (Secchi disk depth). By contrast, headwater streams in the eastern part of the study area (Fig. 5, Group B) were characterized by relatively high agricultural intensity, but low PTI scores and fipronil concentrations, and relatively low water clarity. Mid-basin streams in the central part of the study area (Fig. 5, Group C) were characterized by relatively high agricultural intensity, high PTI scores and fipronil concentrations, and low water clarity. In
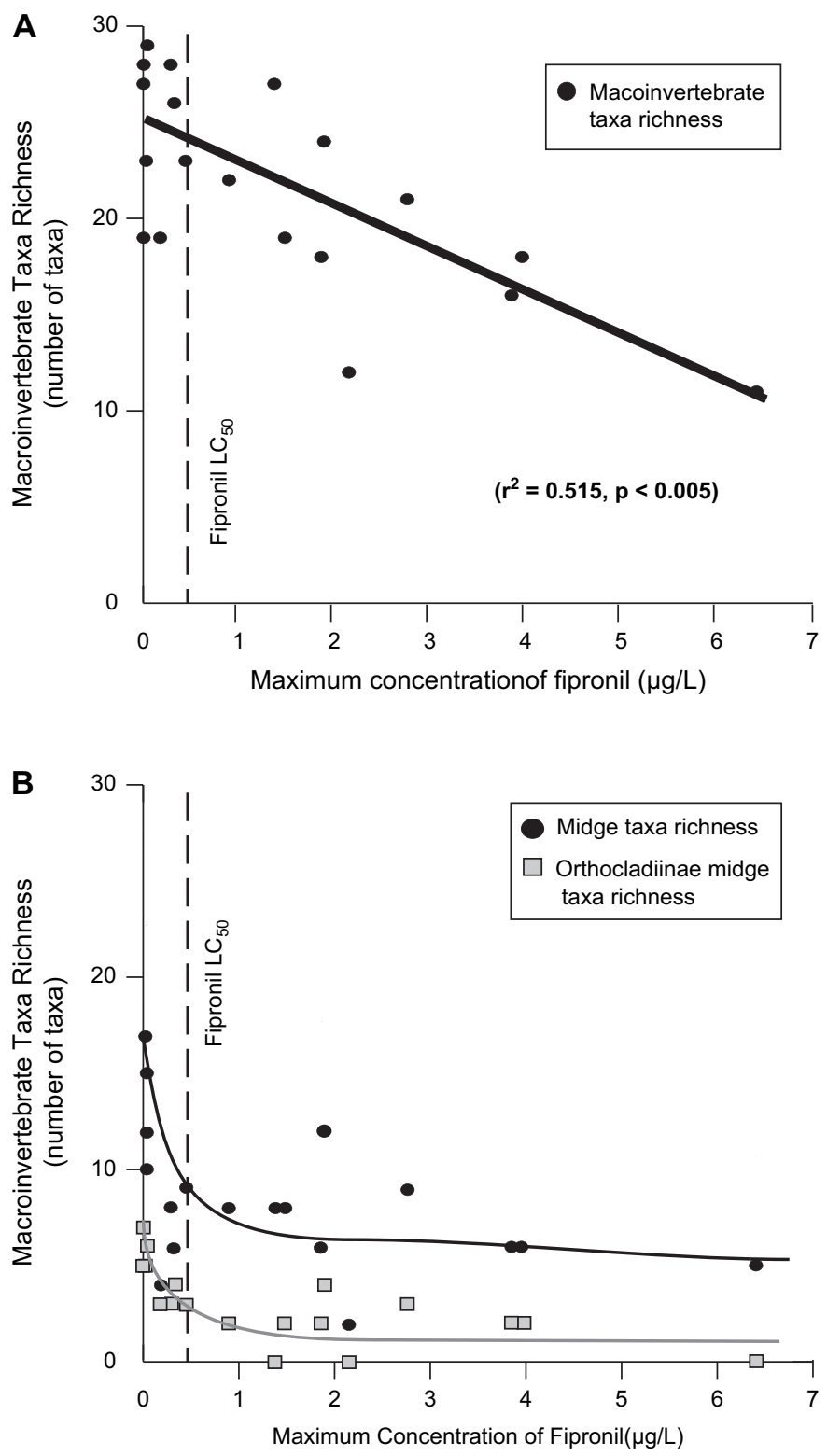

Fig. 3. Relations among richness of macroinvertebrates, midges (Chironomidae) and Orthocladiinae midges, and maximum concentrations of fipronil at sampling sites in southwestern Louisiana, March-May 2001.

the southern part of the study area (Fig. 5, Group D), streams were characterized by high agricultural intensity, as well as moderate PTI scores and fipronil concentrations, relatively low water clarity, and large stream wetted channel width and open canopy.

Most macroinvertebrate taxa collected during the study are considered very tolerant to organic enrichment (e.g., Barbour et al., 1999). Relatively distinct taxa at sites in Group A (Fig. 5) included several midge species (Rheotanytarsus sp., Rheocricotopus sp., and Tanytarsus sp.) including biting midges (Atrichopogon sp. and Bezzia/Palpomyia sp.). Taxa associated with sites in Group B included midges (Thienemannimyia sp., Cricotopus sp.), tolerant mayflies (Caenis sp.), caddisflies (Cheumatopsyche sp.), and unidentified genera in the families 

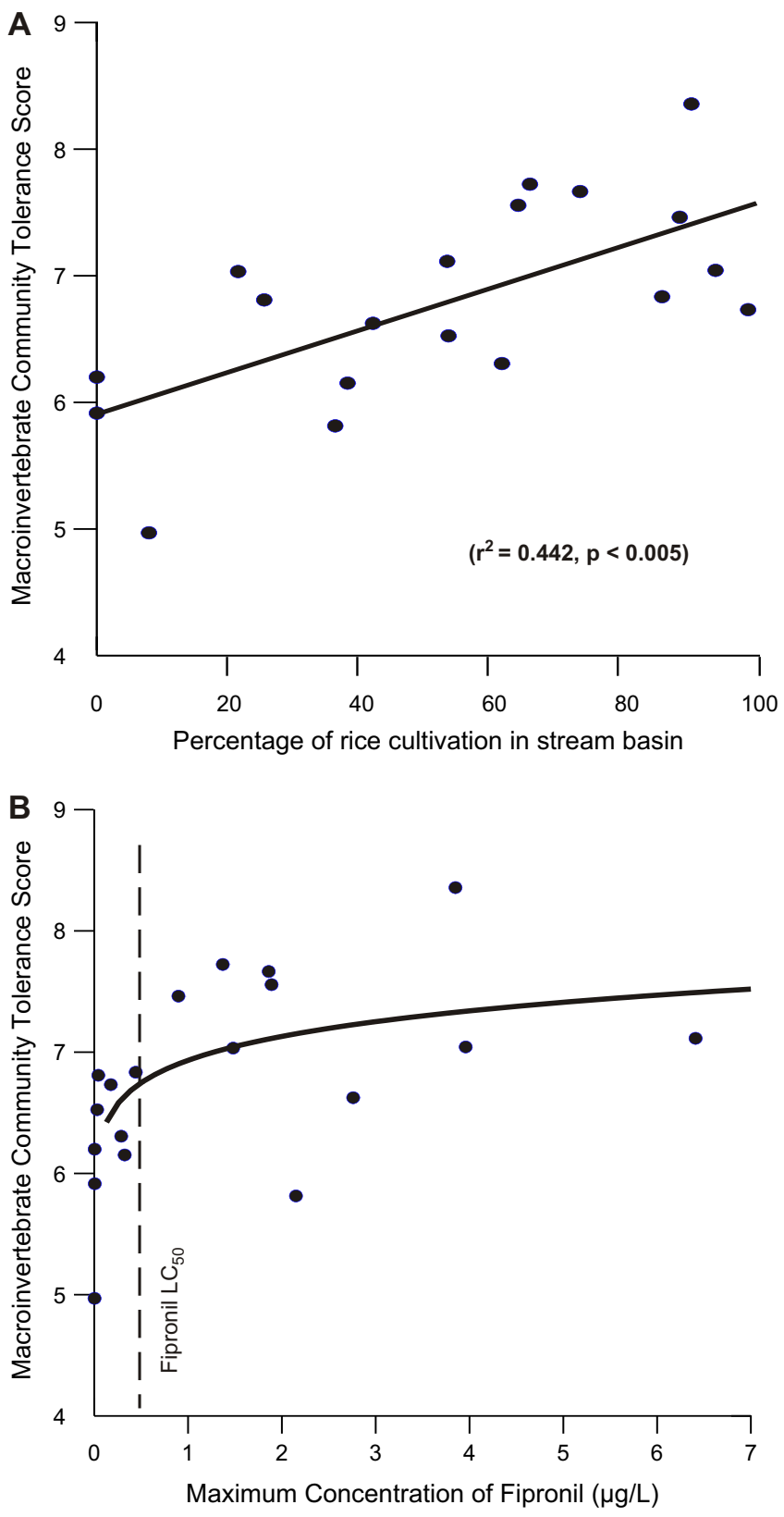

Fig. 4. Macroinvertebrate community-tolerance score and percentage of rice cultivation in stream basin, and maximum concentrations of fipronil at sampling sites in southwestern Louisiana, March-May 2001.

Eropidae and Tubificidae. Snails (Physella sp.), oligochaete worms (Tubificidae; Enchytraeidae), and flatworms (Turbellaria) were relatively more common at mid-basin and large river sites in Groups C and D than at the headwater sites in Groups A and B. Amphipods (Hyalella azteca), midges (Glyptotendipes sp.), and tolerant mayflies (Caenis sp.) also were common at large river sites in Group D.

Although tolerant of organic enrichment, responses of certain macroinvertebrate taxa to fipronil compounds appeared to occur at relatively low concentrations, near the published $\mathrm{LC}_{50}$ values for chironomid midges (ca. $0.5 \mu \mathrm{g} / \mathrm{L}$ ). For example, the relative abundance of Rheotanytarsus decreased rapidly with small increases in fipronil concentrations, and relative abundance rarely exceeded 5\% when fipronil concentrations exceeded $1 \mu \mathrm{g} / \mathrm{L}$ (Fig. 6A). Similarly, the relative abundance of Caenis decreased rapidly in streams as fipronil concentrations approached $2 \mu \mathrm{g} / \mathrm{L}$, and was absent from the macroinvertebrate community at concentrations higher than $2 \mu \mathrm{g} / \mathrm{L}$ (Fig. 6B). Similar relations were determined for other macroinvertebrate taxa, notably midges (Fig. 6C and D). The relative abundance of flatworms in the class Turbellaria (Fig. 6E) and oligochaete worms in the family Enchytraeidae (Fig. 6F) increased at sites with elevated fipronil concentrations.

Patterns of decreased macroinvertebrate abundance and richness, with concurrent increases in the abundance of organisms that apparently tolerate elevated fipronil concentrations also occurred at sites with relatively large concentrations of fipronil degradation products (fipronil sulfide, fipronil sulfone, and desulfinylfipronil). Because of higher toxicity of the sulfide and sulfone degradates (relative to the parent compound) and their strong affinity for streambed sediments, we suggest that organisms associated with sediment may be at higher risk for fipronil-related toxicity. The abundance of snails, oligochaete worms, flatworms, and amphipods at mid and lower basin sites (Groups C and D) likely indicates that those organisms are highly resistant to fipronil compounds.

\section{Discussion}

Macroinvertebrate community structure and metrics commonly are utilized by state and Federal regulatory agencies to assess water quality and stream condition (Thorpe and Covich, 1991; Barbour et al., 1999; Moulton et al., 2002). Indicators of macroinvertebrate-community tolerance to human stresses on aquatic resources (e.g., agricultural and urban land-use activities) traditionally have focused on species tolerance to low concentrations of dissolved oxygen (Hynes, 1960, 1970), a common consequence of high rates of microbial respiration associated with excessive loads of nutrients and (or) carbon, often cited as "organic enrichment." Streams in southwestern Louisiana contain large amounts of carbon from natural sources (riparian vegetation, soils, and wetlands) which contribute to seasonal periods of low dissolved-oxygen concentrations. Thus, larger than expected macroinvertebratetolerance scores and community dominance of tolerant taxa are likely associated with the regional environmental setting (Western Gulf Coastal Plains ecoregion; Omernik, 1987). Despite a strong regional signal, indicators of tolerance increased significantly with agricultural intensity (percentage of rice cultivation) indicating that macroinvertebrate indicators of organic enrichment and human stresses are robust in this environmental setting. In addition to adverse responses associated with nutrient and organic enrichment, agricultural modification of stream channels, riparian zones, and stream-sediment transport processes also contributed to low macroinvertebrate diversity (as taxa richness) and high community tolerance scores in agricultural areas.

Effects of specific pesticides on non-targeted, aquatic organisms generally are difficult to evaluate in monitoring studies, in part because of other chemical and habitat factors 


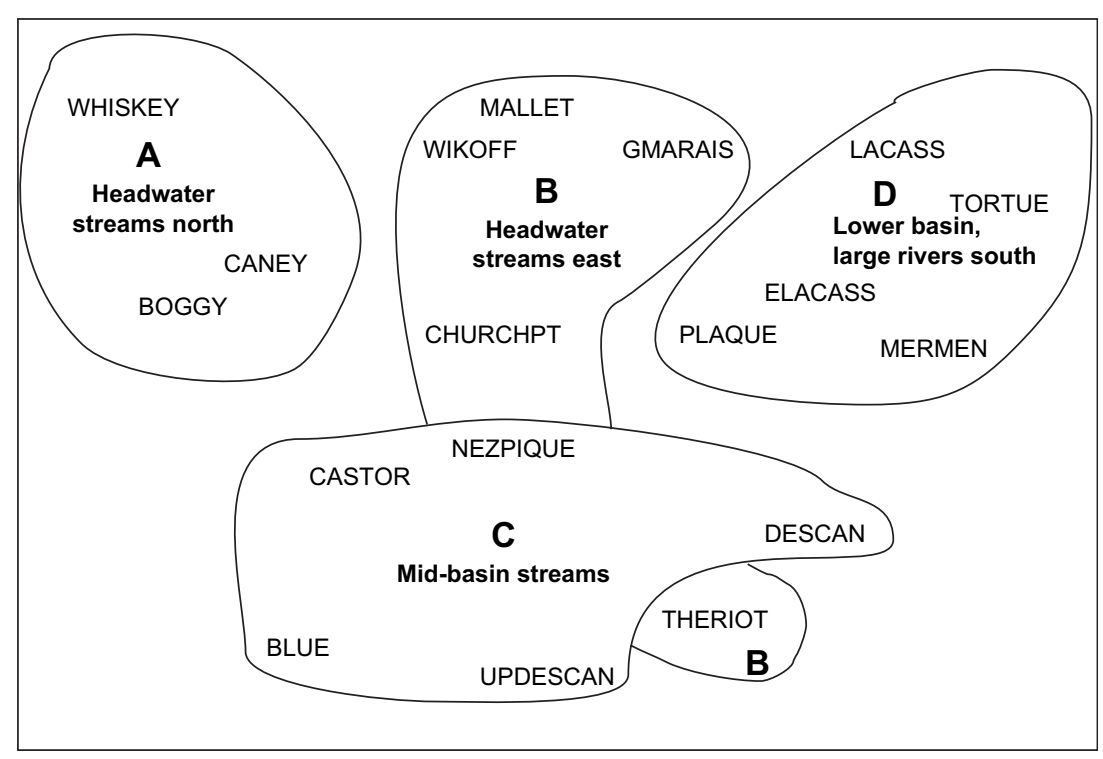

Fig. 5. Site groups (A-D) based on non-metric multidimensional scaling of the relative abundance of macroinvertebrate taxa at sampling sites in southwestern Louisiana, March-May 2001.

that can influence populations and communities, but also because pesticides generally occur as mixtures of insecticides and herbicides in water-quality samples. Laboratory-based toxicity information is not available for many degradation compounds, and the combined effects of pesticide mixtures on aquatic communities are unknown or poorly understood. Moreover, the range of concentrations of potentially toxic pesticides and the duration of time over which aquatic organisms are exposed to these water-quality contaminants cannot be determined in field surveys. The PTI considers potential toxicity of all pesticides detected in water samples, and assumes that toxicity of individual pesticide compounds is additive (Munn and Gilliom, 2001). Although the additive assumption is not likely to be met in field samples, the PTI is still useful as a relative index of potential toxicity. Even though the PTI calculated for this study is dominated numerically by the potential toxicity ( $\mathrm{LC}_{50}$ values) of fipronil and fipronil degradation compounds, concentrations of other insecticide compounds (malathion, carbaryl, carbofuran, and diazinon) also contributed to the PTI. Because of the overriding influence of fipronil compounds on PTI scores for southwestern Louisiana streams, both fipronil concentrations and the PTI were equally effective explanatory factors for macroinvertebratecommunity conditions.

Although taxa richness decreased linearly with increases in fipronil concentrations (Fig. 3), most population and community measures exhibited a threshold response to fipronil, at or near the laboratory $\mathrm{LC}_{50}$ value. Populations of Rheotanytarsus, Caenis, Corynoneura, and Cricotopus decreased rapidly as fipronil concentrations approached about $1-2 \mu \mathrm{g} / \mathrm{L}$; those populations remained small or absent in streams with fipronil concentrations greater than $2 \mu \mathrm{g} / \mathrm{L}$. We suggest that those taxa can be viewed as "indicators," sensitive to fipronil compounds but tolerant of organic enrichment. Similarly, macroinvertebrate community-tolerance scores increased rapidly as fipronil concentrations approached about $1 \mu \mathrm{g} / \mathrm{L}$, with no appreciable change in tolerance scores at sites with larger fipronil concentrations. We hypothesize that taxa with sensitivity to fipronil compounds also are somewhat less tolerant to organic enrichment. As presumed toxicity to fipronil-sensitive organisms increases, communities become dominated by taxa that are highly tolerant both to fipronil and organic enrichment, thus tolerance scores remain relatively constant in streams with elevated fipronil concentrations.

The most notable response in macroinvertebrate-community structure was a shift in dominance from insects (midges, mayflies, and caddisflies) to non-insects (scuds, snails, worms) as rice-cultivation intensity and concentrations of fipronil compounds increased. Although midges generally are considered tolerant to organic enrichment (Barbour et al., 1999), certain midge taxa (notably Tanytarsini and Orthocladiinae) in southwestern Louisiana streams appear to be sensitive to increases in agricultural intensity and fipronil concentrations. Flatworms in the class Turbellaria (Fig. 6E) and oligochaete worms in the family Enchytraeidae (Fig. 6F) and other non-insect taxa appear to be highly tolerant to intensive rice cultivation and relatively large concentrations of fipronil compounds (greater than $2 \mu \mathrm{g} / \mathrm{L}$ ).

The NMDS based on the relative abundance of predominant macroinvertebrate taxa revealed a spatial distribution of sites associated with basin geography, stream size, and ricecultivation intensity. Distributions of environmental values (or scores) in relation to the macroinvertebrate ordination pattern indicate that differences in pesticide concentrations (PTI scores and fipronil compounds), water clarity (as Secchi depth), and habitat conditions (stream wetted channel width, percentage of open canopy) best explained the distribution of sites in relation to community composition and abundance (Fig. 5).

Although potential toxicity from fipronil compounds in water or streambed sediments might be an obvious explanation 

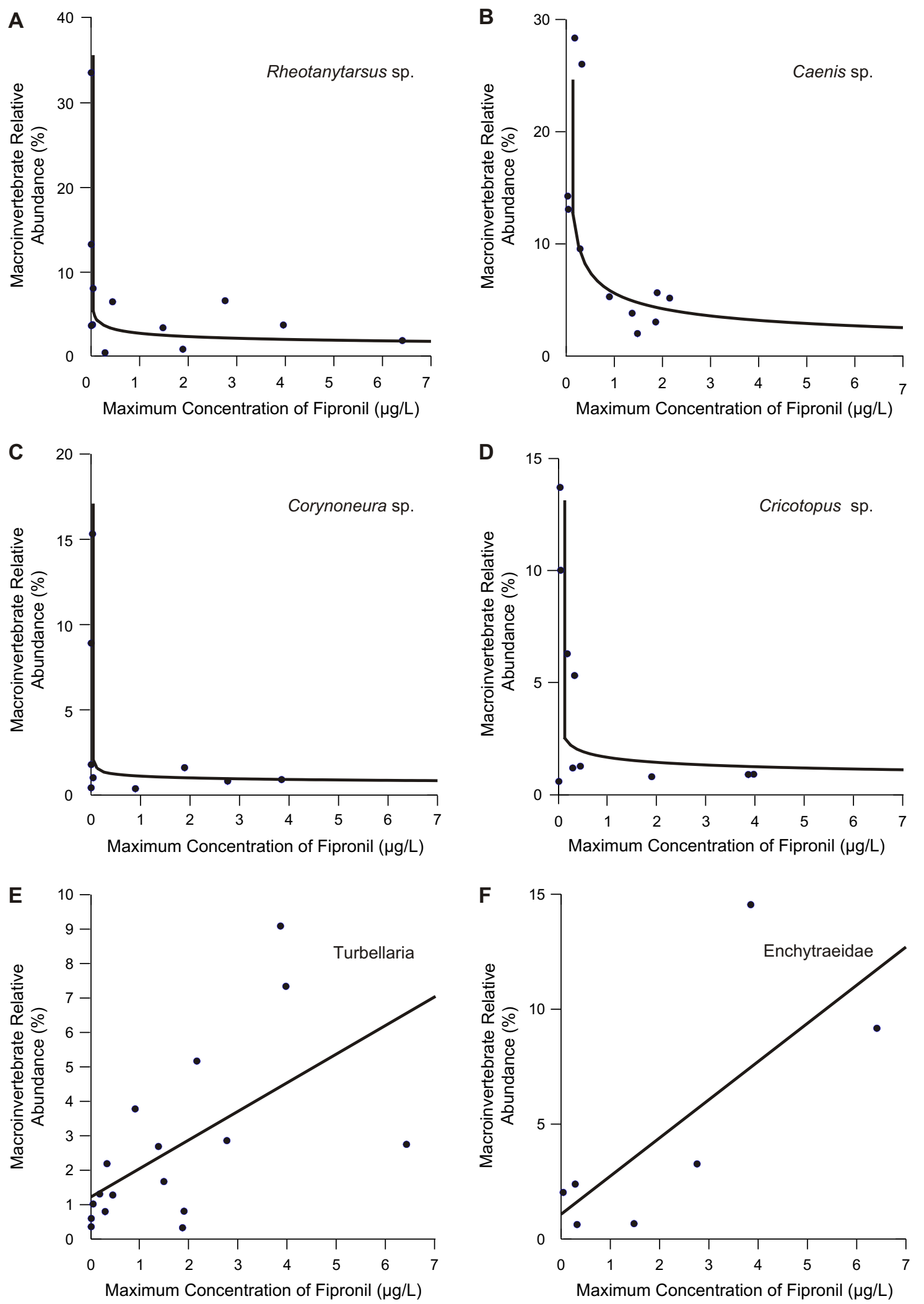

Fig. 6. Relative abundance of Rheotanytarsus sp., Caenis sp., Corynoneura sp., Cricotopus sp., Turbellaria, Enchytraeidae, and maximum concentrations of fipronil at sampling sites in southwestern Louisiana, March-May 2001. 
for differences in macroinvertebrate community structure, differences in habitat conditions (Barbour and Stribling, 1991; Plafkin et al., 1989; Hynes, 1970) and streamflow (Poff et al., 1997) among sites also are likely to have influenced benthic community structure. Species composition changes along the river continuum (Vannote et al., 1980) may also influence changes in communities from headwater to lowland streams. The two-fold sampling design in this study did account for stream order (small and large streams) and agricultural intensity (low and high) but stream size and habitat cannot be ruled out as potentially influencing the community structures observed.

Land and water-use practices associated with agricultural activities in southwestern Louisiana have influenced habitat conditions by modifying natural channel geomorphology (e.g., aggradation of sediment in streams, channelization and clearing of riparian corridors), simplifying stream microhabitat diversity and reducing the availability of riparian food resources. The strong correspondence of communities with water clarity could be a surrogate for the amount of suspended sediment flux (and subsequent deposition) in stream reaches. Similarly, the percentage of open canopy probably reflects differences in riparian-tree density, bank stability, stream temperature and shading. Stream wetted channel width also could be a surrogate for velocity and seasonal differences in dissolved oxygen concentrations. Wide slow moving streams (bayous) in southwestern Louisiana typically are lentic systems with relatively few opportunities for re-aeration. Dissolved-oxygen concentrations generally are low (or with large diel variability), particularly during periods of warm temperature. By contrast, narrow, often shaded, headwater streams in the basin generally drain forested landscapes with larger stream-channel gradients, and are characterized by flowing water, relatively coarser substrate, and dissolved-oxygen concentrations that are more optimal for aquatic macroinvertebrates.

Agricultural uses of fipronil in southwestern Louisiana largely have been discontinued, particularly by farmers with concurrent rice and crawfish cultivation. Although fipronil concentrations in (2004) water samples from the Mermentau River Basin have decreased to levels less than the $\mathrm{LC}_{50}$ (Baumann et al., 2005), longer-term effects of fipronil degradation compounds, particularly for sediment-dwelling organisms such as burrowing mayflies, midges, and other important food resources for fish, waterfowl, and other wildlife, remain unknown. Fipronil sulfone and sulfide are inherently more toxic than the parent compound, and both compounds have an affinity for carbon-rich sediment. Relatively little is known about the accumulation, distribution, and persistence of these fipronil compounds in aquatic sediments (Demcheck and Skrobialowski, 2003), and potential fipronil toxicity to organisms associated with sediment merits further study. Although agricultural use of fipronil has declined in southwestern Louisiana, commercial and residential uses (termite control, household pest control, and veterinary products) of the insecticide appear to be increasing, and the agricultural use of fipronil could extend to other crops and regions. We hope that results from this study, one of the first published field investigations addressing the influence of fipronil compounds on stream macroinvertebrates, will be important in future assessments of water quality and stream conditions.

\section{Conclusion}

The influence of fipronil compounds and rice agricultural intensity on macroinvertebrate communities in streams of southwestern Louisiana was investigated at 19 locations in the Mermentau and Calcasieu River basins. Macroinvertebrate abundance and diversity (as taxa richness) decreased significantly with increases in the percentage of rice cultivation and concentrations of fipronil compounds. Community tolerance metrics increased significantly with agricultural intensity and exhibited a non-linear, threshold response to ambient fipronil concentrations. Population and community tolerance response curves revealed that the maximum rates of change occurred at very low fipronil concentrations, near published laboratory $\mathrm{LC}_{50}$ values.

Predominant taxa in macroinvertebrate communities changed from aquatic insects (midges, mayflies, caddisflies) to non-insects (amphipods, snails, worms) as agricultural intensity and fipronil concentrations increased. Midges appeared to be good indicators of fipronil influences: Rheotanytarsus, Corynoneura, and Cricotopus and various Tanytarsini and Orthocladinae midge taxa appeared to be sensitive to fipronil compounds (but tolerant to organic enrichment). Flatworms in the class Turbellaria and oligochaete worms in the family Enchytraeidae and other non-insect taxa appeared to be highly tolerant to intensive rice cultivation and relatively large concentrations of fipronil compounds (greater than $2 \mu \mathrm{g} / \mathrm{L}$ ).

Non-metric multidimensional scaling of the relative abundance of common macroinvertebrate taxa revealed a pattern of sites associated with basin geography and stream size. Agricultural intensity, fipronil concentrations, water clarity, and stream habitat attributes (channel width and percentage of open canopy) were most closely aligned with the macroinvertebrate ordination, and are thought to exert the strongest influence on community composition. Results from this investigation provide initial understanding of fipronil-macroinvertebrate relations that will be important for future studies, particularly since residential and commercial uses of fipronil appear to be increasing and fipronil may be used on other crops in the future. The affinity of fipronil sulfone and sulfide, compounds with greater toxicity potential than fipronil, for carbon-rich streambed sediments may pose risks for sediment-dwelling macroinvertebrates that are important food resources for fish, waterfowl, and other wildlife.

\section{Acknowledgments}

We thank K. Fontenot, R. Levy, and E. Eskew of the Louisiana Cooperative Extension Service, Louisiana State University Agricultural Center for assistance in evaluating the extent of rice cultivation in the Mermentau River Basin. We gratefully acknowledge S. Skrowbialowski, R. DeWeese, V. Bergeron, J. Brantly, P. Frederick, K. Grimsley, C. Sibley, 
L. Simmons, and W. Snee of the USGS Louisiana Water Science Center for assistance with data collection; and the Biological Group of the USGS National Water Quality Laboratory in Denver, CO, for providing invertebrate taxonomic and abundance data. We thank riparian landowners who granted permission for us to sample. We also thank M. Munn, L. Nowell, and J. Petersen, for critical review comments on this manuscript. Additional information about the NAWQA program and other NAWQA studies in Louisiana can be accessed on the Internet at http://water.usgs.gov/ nawqa/. This paper has been reviewed in accordance with USGS policy. The use of trade, product, industry, or firm names in this report is for descriptive or location purposes only and does not constitute endorsement of products by the US Government nor impute responsibility for any present or potential effects on the natural resources.

\section{References}

Ali, A., Nayar, J.K., Gu, W.D., 1998. Toxicity of a phenylpyrazole insecticide, fipronil, to mosquito and chironomid midge larvae in the laboratory. Journal of the American Mosquito Control Association 14 (2), 216-218.

Barbour, M.T., Stribling, J.B., 1991. Use of habitat assessment in evaluating the biological integrity of stream communities. In: Gibson, G. (Ed.), Biological Criteria: Research and Regulation. Proceedings of a Symposium, 12-13 December 1990. Arlington, Virginia, Washington, DC. EPA-4405-91-005.

Barbour, M.T., Gerritsen, J., Snyder, B.D., Stribling, J.B., 1999. Rapid Bioassessment Protocols for Use in Streams and Wadable Rivers-Periphyton, Benthic Macroinvertebrates and Fish, second ed. EPA-841-B-99-002, Washington, DC.

Baumann, T., Goree, B.B., Lovelace, W.M., Montgomery, P.A., Resweber, J.C., Ross, G.B., Ward, A.N., Walters, D.J., 2005. Water Resources Data-Louisiana, Water Year 2004, US Geological Survey Water-Data Report LA-04-1.

Chandler, G.T., Cary, T.L., Volz, D.C., Walse, S.S., Ferry, J.L., Klosterhaus, S.L., 2004. Fipronil effects on copepod development, fertility, and reproduction: a rapid life-cycle assay in 96-well microplate format. Environmental Toxicology and Chemistry 23, 117-124.

Clarke, K.R., 1993. Nonparametric multivariate analyses of changes in community structure. Australian Journal of Ecology 18, 117-143.

Clarke, K.R., Warwick, R.M., 2001. Change in Marine Communities: An Approach to Statistical Analysis and Interpretation. PRIMER-E Ltd, Plymouth, UK.

Connelly, P., 2001. Environmental fate of fipronil, California Environmental Protection Agency. Department of Pesticide Regulation. http:// www.pw.ucr.edu/textfiles/fipronil.pdf (accessed Jan 10, 2007).

Cuffney, T.F., 2003. User's Manual for the National Water-Quality Assessment Program Invertebrate Data Analysis System (IDAS) Software, version 3. US Geological Survey Open-File Report 03-172.

Demcheck, D.K., Skrobialowski, S.C., 2003. Fipronil and Degradation Products in the Rice-producing Areas of the Mermentau River Basin, Louisiana, February-September 2000. US Geological Survey Fact Sheet FS-010-03.

Demcheck, D.K., Tollett, R.W., Mize, S.V., Skrobialowski, S.C., Fendick Jr., R.B., Swarzenski, C.M., Porter, S.D., 2004. Water Quality in the Acadian-Pontchartrain Drainages, Louisiana and Mississippi, 1999-2001. US Geological Survey Circular 1232.

Fishman, M.J., Friedman, L.C., 1989. Methods for determination of inorganic substances in water and fluvial sediments. Techniques of Water-Resources Investigations of the US Geological Survey.

Fitzpatrick, F.A., Waite, I.R., D’Arconte, P.J., Meador, M.R., Maupin, M.A., Gurtz, M.E., 1998. Revised Methods for Characterizing Stream Habitat in the National Water-Quality Assessment Program. US Geological Survey Water-Resources Investigations Report 98-4052.

Frear, D.E.H., Boyd, J.E., 1967. Use of Daphnia magna for the microbioassay of Pesticides. I. Development of standardized techniques for rearing Daphnia and preparation of dosage mortality curves for pesticides. Journal of Economic Entomology 60 (5), 1228-1236.

Gilliom, R.J., Alley, W.M., Gurtz, M.E., 1995. Design of the National WaterQuality Assessment Program: Occurrence and Distribution of WaterQuality Conditions. US Geological Survey Circular 1112.

Hainzl, D., Casida, J.E., 1996. Fipronil insecticide: novel photochemical desulfinylation with retention of neurotoxicity. Proceedings of the National Academy of Sciences of the United States of America 93 (23), 12764-12767.

Hynes, H.B.N., 1960. The Biology of Polluted Waters. Liverpool University Press, Liverpool, UK.

Hynes, H.B.N., 1970. The Ecology of Running Waters. University Press, Liverpool, UK.

Kruskal, J.B., 1964. Multidimensional scaling by optimizing goodness of fit to a nonmetric hypothesis. Psychometrika 29, 1-27.

Madsen, J.E., Sandstrom, M.W., Zaugg, S.D., 2003. Methods of Analysis by the US Geological Survey National Water Quality Laboratory-A Method Supplement for the Determination of Fipronil and Degradates in Water by Gas Chromatography/Mass Spectrometry. US Geological Survey OpenFile Report 02-462.

Moulton II, S.R., Carter, J.L., Grotheer, S.A., Cuffney, T.F., Short, T.M., 2000. Methods of analysis by the US Geological Survey National Water Quality Laboratory-Processing, Taxonomy, and Quality Control of Benthic Macroinvertebrate Samples. US Geological Survey Open-File Report 00-212.

Moulton II, S.R., Kennen, J.G., Goldstein, R.M., Hambrook, J.A., 2002. Revised protocols for sampling algal, invertebrate, and fish communities as part of the National Water-Quality Assessment Program. US Geological Survey Open-File Report $02-150$.

Mueller, D.K., Martin, J.D., Lopes, T.J., 1997. Quality-control Design for Surface-water Sampling in the National Water-Quality Assessment Program. US Geological Survey Open-File Report 97-223.

Munn, M.D., Gilliom, R.J., 2001. Pesticide Toxicity Index for Freshwater Aquatic Organisms. US Geological Survey Water-Resources Investigations Report 01-4077.

National Pesticide Telecommunications Network, 1997. Fipronil, NPTN Fact Sheet. Oregon State University, Corvallis, OR, USA. http://npic.orst.edu/ factsheets/fipronil.pdf (accessed April 6, 2005).

Omernik, J.M., 1987. Ecoregions of the conterminous United States on a scale of 1:7,500,000. Annuals of the Association of American Geographers 77, $118-125$.

Overmyer, J.P., Mason, B.N., Armbrust, K.L., 2005. Acute toxicity of imidacloprid and fipronil to a nontarget aquatic insect, simulium vittatum zetterstedt cytospecies IS-7. Bulletin of Environmental Contamination and Toxicology 74, 872-879.

Plafkin, J.L., Barbour, M.T., Porter, K.D., Gross, S.K., Hughes, R.M., 1989. Rapid Bioassessment Protocols for Use in Streams and Rivers: Benthic Macroinvertebrates and Fish. US Environmental Protection Agency, Office of Water Regulations and Standards, Washington, DC. EPA-440-4-89-001.

Poff, N.L., Aleen, J.D., Bain, M.B., Karr, J.R., Prestegaard, K.L., Richter, B.D., Sparks, R.E., Stomberg, J.C., 1997. The natural flow regime: a new paradigm for river conservation and restoration. BioScience 47, 769-784.

Sandstrom, M.W., 1995. Filtration of Water-sediment Samples for the Determination of Organic Compounds, US Geological Survey Water-Resources Investigations Report 95-4105.

Sandstrom, M.W., Wydoski, D.S., Schroeder, M.P., Zamboni, J.L., Foreman, W.T., 1992. Methods of Analysis by the US Geological Survey National Water Quality Laboratory-Determination of Organonitrogen Herbicides in Water by Solid-phase Extraction and Capillary-column Gas Chromatography/Mass Spectrometry with Selected-ion Monitoring. US Geological Survey Open-File Report 91-519.

Shelton, L.R., 1994. Field Guide for Collecting and Processing Stream-water Samples for the National Water Quality Assessment Program. US Geological Survey Open File Report 94-0445. 
Skrobialowski, S.C., Mize, S.V., Demcheck, D.K., 2004. Environmental setting, water quality, and ecological indicators of surface-water quality in the Mermentau River Basin, southwestern Louisiana, 1998-2001, US Geological Survey Water-Resources Investigations Report 03-4185.

Stevens, M.M., Helliwell, S., Warren, G.N., 1998. Fipronil seed treatments for the control of chironomid larvae (Diptera: Chironomidae) in aerially-sown rice crops. Field Crops Research 57, 195-207.

ter Braak, C.J.F., Smilauer, P., 1998. CANOCO Reference Manual and User's Guide to Canoco for Windows-Software for Canonical Community Ordination Version 4. Microcomputer Power, New York.

Thorpe, J.H., Covich, A.P. (Eds.), 1991. Ecology and Classification of North American Freshwater Invertebrates. Academic Press, Inc, San Diego, CA.

US Environmental Protection Agency, 1996. New Pesticide Fact Sheet, PB96-181516. US EPA Office of Prevention, Pesticides, and Toxic Substances. EPA737-F- 96-005.

US Environmental Protection Agency, 1998. Fipronil for use on Rice (Regent, Icon) and Pets (Frontline), HED Risk Assessment. US EPA Office of Prevention, Pesticides, and Toxic Substances, Washington DC.

US Geological Survey, 2001. National Field Manual for the Collection of Water-Quality Data. US Geological Survey Techniques of Water-Resources
Investigations. http://pubs.water.usgs.gov/twri9A. book 9, chaps. A1-A9, 2 vols., variously paged; also available at.

Vannote, R.L., Minshall, G.W., Cummins, K.W., Sedell, J.R., Cushing, C.E., 1980. The river continuum concept. Canadian Journal of Fish and Aquatic Science 37, 130-137.

Weed Science Society of America, 1989. In: Herbicide Handbook, sixth ed. Weed Science Society of America, Champaign, IL.

Weed Science Society of America, 1994. In: Herbicide Handbook, seventh ed. Weed Science Society of America, Champaign, IL.

Wilkinson, L., Coward, M., 1998. Linear models I - linear regression. In: Wilkinson, L. (Ed.), SYSYTAT 8.0 Statistics. SPSS Inc, Chicago, IL, pp. 369-400.

Wilkinson, L., Engelman, L., Marcantonio, R., 1998. Correlations, similarities, and distance measures. In: Wilkinson, L. (Ed.), SYSTAT 8.0 Statistics. SPSS Inc, Chicago, IL, pp. 115-148.

Zaugg, S.D., Sandstrom, M.W., Smith, S.G., Fehlberg, K.M., 1995. Methods of Analysis by the US Geological Survey National Water Quality LaboratoryDetermination of Pesticides in Water by C-18 Solid-phase Extraction and Capillary-Column Gas Chromatography/Mass Spectrometry with Selected-ion Monitoring. US Geological Survey Open-File Report 95-181. 